\title{
Complexation of $\mathrm{NpO}_{2}^{+}$with $\mathrm{N}$-methyl-iminodiacetic Acid: in Comparison with Iminodiacetic and Dipicolinic Acids
}

\author{
Guoxin Tian, and Linfeng Rao ${ }^{a^{*}}$
}

\begin{abstract}
${ }_{5}$ Complexation of $\mathrm{Np}(\mathrm{V})$ with $N$-methyl-iminodiacetic acid (MIDA) in $1 \mathrm{M} \mathrm{NaClO}_{4}$ solution was studied with multiple techniques including potentiometry, spectrophotometry, and microcalorimetry. The 1:2 complex, $\mathrm{NpO}_{2}$ (MIDA) $)_{2}{ }^{3-}$ was identified for the first time in aqueous solution. The correlation between its optical absorption properties and symmetry was discussed, in comparison with $\mathrm{Np}(\mathrm{V})$ complexes with two structurally related nitrilo-dicarboxylic acids,

10 iminodiacetic acid (IDA) and dipicolinic acid (DPA). The order of the binding strength (DPA > MIDA > IDA) is explained by the difference in structural and electronic properties of the ligands. In general, the nitrilo-dicarboxylates form stronger complexes with $\mathrm{Np}(\mathrm{V})$ than oxy-dicarboxylates due to a much more favorable enthalpy of complexation.
\end{abstract}

\section{Introduction}

${ }_{15}$ Neptunium is a "problematic" element in spent nuclear fuel reprocessing because it could exist in multiple oxidation states (e.g., IV, V and VI) and the most stable oxidation state, $\mathrm{NpO}_{2}{ }^{+}$, has very low extractability in solvent extraction separation processes due to its low ionic charge. In the 20 development of advanced nuclear fuel cycles, there is an urgent need to search for ligands that could form strong complexes with $\mathrm{NpO}_{2}{ }^{+}$and make it extractable in solvent extraction.

In recent years, a group of oxy- and nitrilo- dicarboxylic 25 acids and their diamide derivatives have been the subject of study for the complexation of actinides. For the series of oxyligands from oxydiacetic acid (ODA), to $N, N$-dimethyl-3-oxaglutarimic acid (DMOGA), and to $N, N, N$, $N$ '-tetramethyl-3oxa-glutaramide (TMOGA), thermodynamic data show that 30 they all form moderately strong tridentate complexes with $\mathrm{NpO}_{2}{ }^{+}$, and that there are systematic changes in enthalpy and entropy of complexation when the carboxylate group is replaced with the amide group. ${ }^{1,2}$ For the nitrilo ligands, iminodiacetic acid (IDA) $)^{3,4}$ and dipicolinic acid (DPA) ${ }^{5}$ form 35 quite strong tridentate complexes with $\mathrm{NpO}_{2}{ }^{+}$. The amide derivatives of DPA have been shown to be effective for extracting actinides in various oxidation states. ${ }^{6-8}$ These studies have helped with the development of effective extractants for actinide separations.

40 Besides providing help with the separation processes, the studies of the series of oxy- and nitrilo- dicarboxylic acids and their diamide derivatives have also revealed some fundamental properties of the $\mathrm{Np}(\mathrm{V})$ complexes. For example, the optical absorption properties of $\mathrm{Np}(\mathrm{V})$ complexes were 45 experimentally shown to be closely related to the symmetry of the complexes. ${ }^{2,4,5,9,10}$ The 1:2 Np(V) complexes with ODA, ${ }^{9}$ $\mathrm{TMOGA}^{2}$ and $\mathrm{DPA}^{5}$ all have an inversion center (at the Np atom). The $\mathrm{f}-\mathrm{f}$ transitions in these 1:2 $\mathrm{Np}(\mathrm{V})$ complexes are completely forbidden and no characteristic optical absorption 50 bands in the near IR regions are observed for $\mathrm{NpO}_{2}(\mathrm{ODA})_{2}{ }^{3-}$, $\mathrm{NpO}_{2}(\mathrm{TMOGA})_{2}{ }^{+}$, or $\mathrm{NpO}_{2}(\mathrm{DPA})_{2}{ }^{3-}$. In contrast, though IDA ligand forms similar tridentate complexes with $\mathrm{Np}(\mathrm{V})$, its $1: 2$ $\mathrm{Np}(\mathrm{V})$ complex, $\mathrm{NpO}_{2}(\mathrm{IDA})_{2}{ }^{3-}$, does show characteristic absorption bands. ${ }^{4}$ This observation was interpreted as the co55 existence of trans- and cis- isomers, depending on the positions of the two imino-hydrogen atoms with respect to the equatorial plane of $\mathrm{NpO}_{2}{ }^{+}$. The energy difference between the two configurations is expected to be small. The cis-isomer, with the imino-hydrogen atoms on the same side of the plane, 60 is obviously not centrosymmetric and should absorb in the near IR region. The trans- isomer of $\mathrm{NpO}_{2}(\mathrm{IDA})_{2}{ }^{3-}$ is centrosymmetric and does not absorb. ${ }^{10}$

Fig. $1 \mathrm{~N}$-methyl-iminodiacetic acid (MIDA), iminodiacetic acid (IDA), 65 and dipicolinic acid (DPA).

Substitution of the imino hydrogens in IDA with the methyl groups in $N$-methyl-iminodiacetic acid (MIDA, Fig.1) could have significant consequence in the symmetry of the $1: 2$
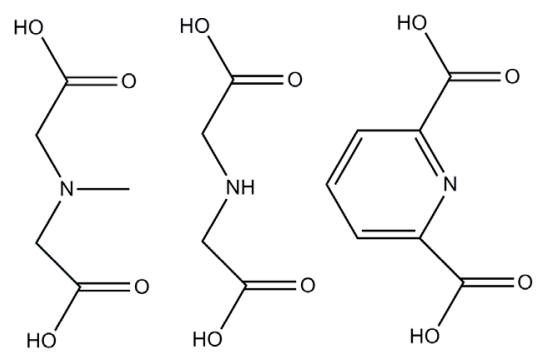

MIDA

IDA

DPA

$\mathrm{Np}(\mathrm{V})$ complexes with MIDA. A cis- isomer of ${ }_{70} \mathrm{NpO}_{2}$ (MIDA) ${ }_{2}{ }^{3-}$ with the two methyl groups on the same side of the equatorial plane is less likely to form, because the steric hindrance in the cis-configuration of $\mathrm{NpO}_{2}$ (MIDA) $)_{2}{ }^{3-}$ is large so that the energy of the cis- isomer is significantly higher than the trans- isomer. In fact, a crystal structure of ${ }_{75} \mathrm{NpO}_{2}(\mathrm{MIDA})_{2}{ }^{3-}$ with the methyl groups trans- to the equatorial plane of $\mathrm{NpO}_{2}{ }^{+}$was identified, ${ }^{11}$ but no cisstructure of $\mathrm{NpO}_{2}$ (MIDA) ${ }_{2}{ }^{3-}$ has been found.

Though MIDA is expected to form similar tridentate 1:1 and 1:2 complexes with $\mathrm{Np}(\mathrm{V})$ in aqueous solutions as IDA 80 and DPA, only the 1:1 complex, $\mathrm{NpO}_{2}$ (MIDA)- has been observed in previous studies. ${ }^{12,13}$ We hypothesize that the $1: 2$ 
complex, $\mathrm{NpO}_{2}$ (MIDA) ${ }_{2}{ }^{3-}$, should also form in aqueous solution and that it possesses an inversion center so that it might have been "missed" in the previous study by spectrophotometry $^{12}$ due to its "silence" in the near IR 5 absorption spectra.

To reveal the thermodynamic principle and structural factors governing the coordination chemistry of $\mathrm{Np}(\mathrm{V})$ and help to improve the efficiency of $\mathrm{Np}(\mathrm{V})$ in separation processes, we have studied the complexation of $\mathrm{Np}(\mathrm{V})$ with 10 MIDA in aqueous solutions in this work, in comparison with IDA and DPA. For the first time, spectrophotometric titrations have shown that $\mathrm{NpO}_{2}(\mathrm{MIDA})_{2}{ }^{3-}$ forms in solution but does not absorb in the near IR region, suggesting a centrosymmetric structure in solution. Thermodynamic 15 parameters $\left(\log \beta, \Delta H \text { and } \Delta S \text { ) of } \mathrm{NpO}_{2} \text { (MIDA) }\right)^{-}$and $\mathrm{NpO}_{2}$ (MIDA) ${ }_{2}{ }^{3-}$ were determined by a combination of potentiometry, spectrophotometry and microcalorimetry. To compare with the $\mathrm{Np}(\mathrm{V}) / \mathrm{IDA}$ system, new data on the stability constants (by potentiometry) and enthalpy (by 20 microcalorimetry) of $\mathrm{NpO}_{2}(\text { IDA })^{-}$and $\mathrm{NpO}_{2}$ (IDA) ${ }_{2}{ }^{3-}$ have also been obtained and included in this paper.

\section{Experimental}

\section{Chemicals}

All chemicals were reagent-grade or higher. Boiled/cooled ${ }_{25}$ Milli-Q water was used in preparation of all solutions. All experiments were conducted at $25{ }^{\circ} \mathrm{C}$ and an ionic strength of 1.0 $\mathrm{M}\left(\mathrm{NaClO}_{4}\right)$. The stock solution of $\mathrm{Np}(\mathrm{V})$ in perchloric acid was prepared as described elsewhere. ${ }^{14}$ The concentration of $\mathrm{Np}(\mathrm{V})$ was determined by the absorbance at $980.2 \mathrm{~nm}(\varepsilon=$ $\left.30395 \mathrm{M}^{-1} \cdot \mathrm{cm}^{-1}\right)$. The concentration of perchloric acid in the stock solution was determined by Gran's titration. ${ }^{15} \mathrm{~N}$-methyliminodiacetic acid (MIDA, 99\%) and iminodiacetic acid (IDA, 98\%, Aldrich) were used as received. Buffered MIDA and IDA solutions were prepared by neutralizing weighted 35 acids with a standard $\mathrm{NaOH}$ solution $(0.999 \pm 0.00196 \mathrm{M}$, Brinkmann) and diluting to appropriate concentrations.

\section{Potentiometry}

The electrode potential ( $E$, in millivolts) was measured with a Metrohm pH meter (Model 713) equipped with a Ross 40 combination $\mathrm{pH}$ electrode (Orion Model 8102) under inert atmosphere (Ar). The original inner solution $(3 \mathrm{M} \mathrm{KCl})$ of the electrode was replaced with $1 \mathrm{M} \mathrm{NaCl}$ to reduce the electrode junction potential. Prior to each titration, an acid-base titration with standard $\mathrm{HClO}_{4}$ and $\mathrm{NaOH}$ solutions was performed to 45 obtain the electrode parameters which allowed the calculation of hydrogen ion concentrations from the electrode potential in the following titration. Multiple titrations were conducted with solutions of different concentrations of $\mathrm{Np}(\mathrm{V})\left(C_{\mathrm{Np}}\right.$ for total $\mathrm{Np}(\mathrm{V}))$, MIDA or IDA ( $C_{\mathrm{L}}$ for total ligand), and different ${ }_{50}$ acidity $\left(C_{\mathrm{H}}\right.$ for total hydrogen ion). For determining the protonation constant of MIDA, $20 \mathrm{~mL}$ of MIDA solutions $\left(C_{\mathrm{L}}\right.$ : 0.02-0.025 M; $\left.C_{\mathrm{H}}: 0.04-0.08 \mathrm{M}\right)$ were titrated with $0.1 \mathrm{M}$ $\mathrm{NaOH}$ solution, and $100-200$ data points were collected in each titration. For determining the stability constants of the ${ }_{55} \mathrm{~Np}(\mathrm{~V}) / \mathrm{MIDA}$ and $\mathrm{Np}(\mathrm{V}) / \mathrm{IDA}$ complexes, $6 \mathrm{~mL}$ of $\mathrm{Np}(\mathrm{V})$ solutions $\left(C_{\mathrm{Np}}: 1.00-2.00 \mathrm{mM} ; C_{\mathrm{H}}: 1.21-2.42 \mathrm{mM}\right.$ ) were titrated with $0.020-0.050 \mathrm{M} \mathrm{Na}$ (MIDA) or $\mathrm{Na}_{2}$ (IDA) solutions, and about 40 - 50 data points were collected for each titration. The protonation constants of MIDA and the 60 stability constants of $\mathrm{Np}(\mathrm{V}) / \mathrm{MIDA}$ and $\mathrm{Np}(\mathrm{V}) / \mathrm{IDA}$ complexes were calculated using the nonlinear regression program Hyperquad 2006. ${ }^{16}$

\section{Spectrophotometry}

Spectrophotometric titrations of $\mathrm{Np}(\mathrm{V})$ were carried out on a ${ }_{65}$ Cary 6000i spectrophotometer (Varian Inc.) from 1150 to 950 $\mathrm{nm}$ with an interval of $0.1 \mathrm{~nm}$. The $\mathrm{Np}(\mathrm{V})$ solution $(2.5 \mathrm{~mL})$ was put in a $1 \mathrm{~cm}$ cuvette and titrated with buffered MIDA solutions. After each addition of the titrant, the solution was mixed thoroughly (for $1-2$ minutes) before the spectrum was 70 collected. Preliminary kinetic experiments showed that the complexation reaction was fast, and the absorbance became stable within 30 seconds of mixing. Usually, $15-20$ additions were made, generating a set of $16-21$ spectra in each titration. Multiple titrations with different concentrations of ${ }_{75} \mathrm{~Np}(\mathrm{~V})$ were performed. The formation constants of $\mathrm{Np}(\mathrm{V}) / \mathrm{MIDA}$ complexes were calculated by Hyperquad 2006.

\section{Microcalorimetry}

Calorimetric titrations were conducted at $25{ }^{\circ} \mathrm{C}$ with an isothermal microcalorimeter (Model: ITC 4200, Calorimetry ${ }_{80}$ Sciences Corp.). Procedures and results of the calibration of the calorimeter were provided elsewhere. ${ }^{17}$ Three titrations with different concentrations of $\mathrm{Np}(\mathrm{V})(1.0-2.5 \mathrm{mM})$ were performed to reduce the uncertainty of the results. In each titration, $0.9 \mathrm{~mL}$ of $\mathrm{Np}(\mathrm{V})$ solution was put in the reaction 85 cell, and $n$ additions of $0.005 \mathrm{~mL}$ of the titrant (MIDA or IDA) were made $(n=40-50)$ through a $0.250 \mathrm{~mL}$ syringe, resulting in $n$ experimental values of total heat $\left(Q_{\mathrm{ex}, j}, j=1\right.$ to $n)$. These values were corrected for the heats of titrant dilution $\left(Q_{\mathrm{dil}, j}\right)$ that were measured in a separate run. The net reaction 90 heat at the $j$ th point $\left(Q_{\mathrm{r}, j}\right)$ was obtained from the difference: $Q_{\mathrm{r}, j}=Q_{\mathrm{ex}, j}-Q_{\mathrm{dil}, j}$. The value of $Q_{\mathrm{r}, j}$ is a function of the concentrations of the reactants $\left(C_{\mathrm{Np}}, C_{\mathrm{H}}\right.$, and $\left.C_{\mathrm{L}}\right)$, the equilibrium constants, and the enthalpies of the reactions that occurred in the titration. These data, in conjunction with the 95 protonation constants obtained by potentiometry, the stability constants of $\mathrm{Np}(\mathrm{V}) / \mathrm{MIDA}$ and $\mathrm{Np}(\mathrm{V}) / \mathrm{IDA}$ obtained by potentiometry and/or spectrophotometry, and the enthalpy of protonation of MIDA and IDA determined in separate microcalorimetric titrations, were used to calculate the

100 enthalpy of compexation for $\mathrm{Np}(\mathrm{V}) / \mathrm{MIDA}$ and $\mathrm{Np}(\mathrm{V}) / \mathrm{IDA}$ complexes with the computer program Letagrop. ${ }^{18}$

\section{Results and Discussion}

Equilibrium constants and enthalpy of protonation of MIDA 
MIDA has three protonation sites: the amino nitrogen and the two carboxylate oxygens. The overall protonation constants and entahlpy of protonation determined in this work are shown in Table 1. The protonation constants are consistent 5 with those at other ionic strengths in the literature. ${ }^{19}$ The enthalpies of protonation, $\Delta H_{1}$ for $\left(\mathrm{H}^{+}+\mathrm{MIDA}^{2-}=\mathrm{H}(\mathrm{MIDA})^{-}\right.$ ) and $\Delta H_{2}$ for $\left(2 \mathrm{H}^{+}+\mathrm{MIDA}^{2-}=\mathrm{H}_{2}(\mathrm{MIDA})(\mathrm{aq})\right)$, are the first such values directly determined by microcalorimetry. The enthalpy of the third protonation reaction, $\Delta H_{3}$ for $\left(3 \mathrm{H}^{+}+\right.$ ${ }_{10} \mathrm{MIDA}^{2-}=\mathrm{H}_{3}(\mathrm{MIDA})^{+}$) was not determined in this work, because this reaction only occurs in strongly acidic solutions and the value of $\Delta H_{3}$ is not needed in the calculation of the enthalpy of $\mathrm{Np}(\mathrm{V}) / \mathrm{MIDA}$ complexation under the conditions in this work.

${ }_{15}$ Stability constants of $\mathbf{N p}(\mathrm{V}) / \mathrm{MIDA}$ and $\mathbf{N p}(\mathrm{V}) / \mathrm{IDA}$ complexes by potentiometry

Fig. 2 shows representative potentiometric titrations of $\mathrm{Np}(\mathrm{V})$ with MIDA and IDA. The best fit of the titration data indicates that two successive complexes (1:1 and 1:2) formed 20 during the titration. The calculated stability constants are summarized in Table 1.

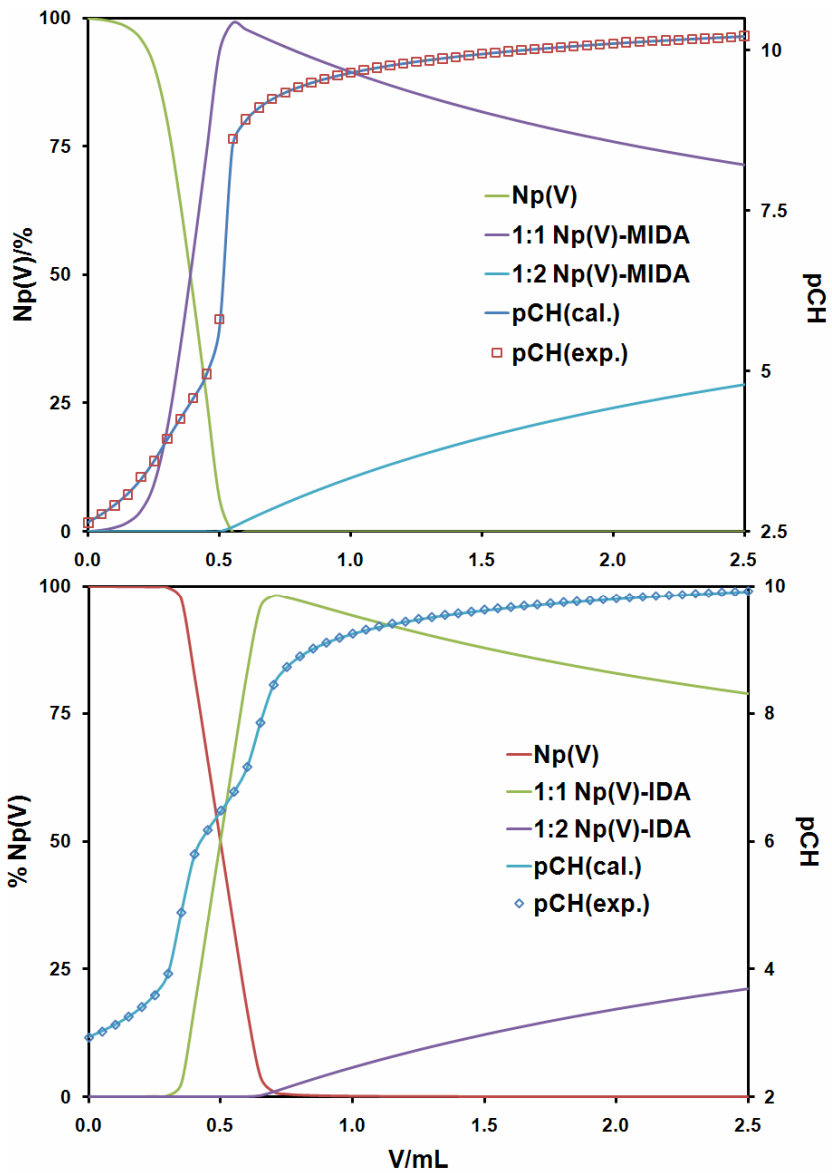

Fig. 2 Potentiometric titrations of $\mathrm{Np}(\mathrm{V})$ complexation with MIDA and IDA $\left(t=25^{\circ} \mathrm{C}, I=1.0 \mathrm{M} \mathrm{NaClO}_{4}\right)$. (top) $\mathrm{Np}(\mathrm{V}) / \mathrm{MIDA}: V_{0}=6 \mathrm{~mL}, C_{\mathrm{Np}}{ }^{0}$ $=2.03 \mathrm{mM}, C_{\mathrm{H}}{ }^{0}=2.30 \mathrm{mM}$, titrant $-0.050 \mathrm{M} \mathrm{Na}$ MIDA. (bottom) $25 \mathrm{~Np}(\mathrm{~V}) /$ IDA: $V_{0}=6.00 \mathrm{~mL}, C_{\mathrm{Np}}{ }^{0}=1.01 \mathrm{mM}, C_{\mathrm{H}}{ }^{0}=1.16 \mathrm{mM}$, titrant $0.020 \mathrm{M} \mathrm{Na}_{2}$ IDA. Right y-axis: $\mathrm{p} C_{\mathrm{H}}\left(=-\log \left[\mathrm{H}^{+}\right]\right)$; left y-axis: \% of $\mathrm{Np}(\mathrm{V})$ species.
The stability constant of the 1:1 complex, $\mathrm{NpO}_{2}$ (MIDA)', $\left(\log \beta_{1}=7.36\right.$ at $\left.I=1 \mathrm{M}\right)$ is consistent with the values at other 30 ionic strengths in the literature. The stability constant of the $1: 2$ complex, $\mathrm{NpO}_{2}(\mathrm{MIDA})_{2}{ }^{3-}$, is the first data available. This complex has not been identified in previous studies.
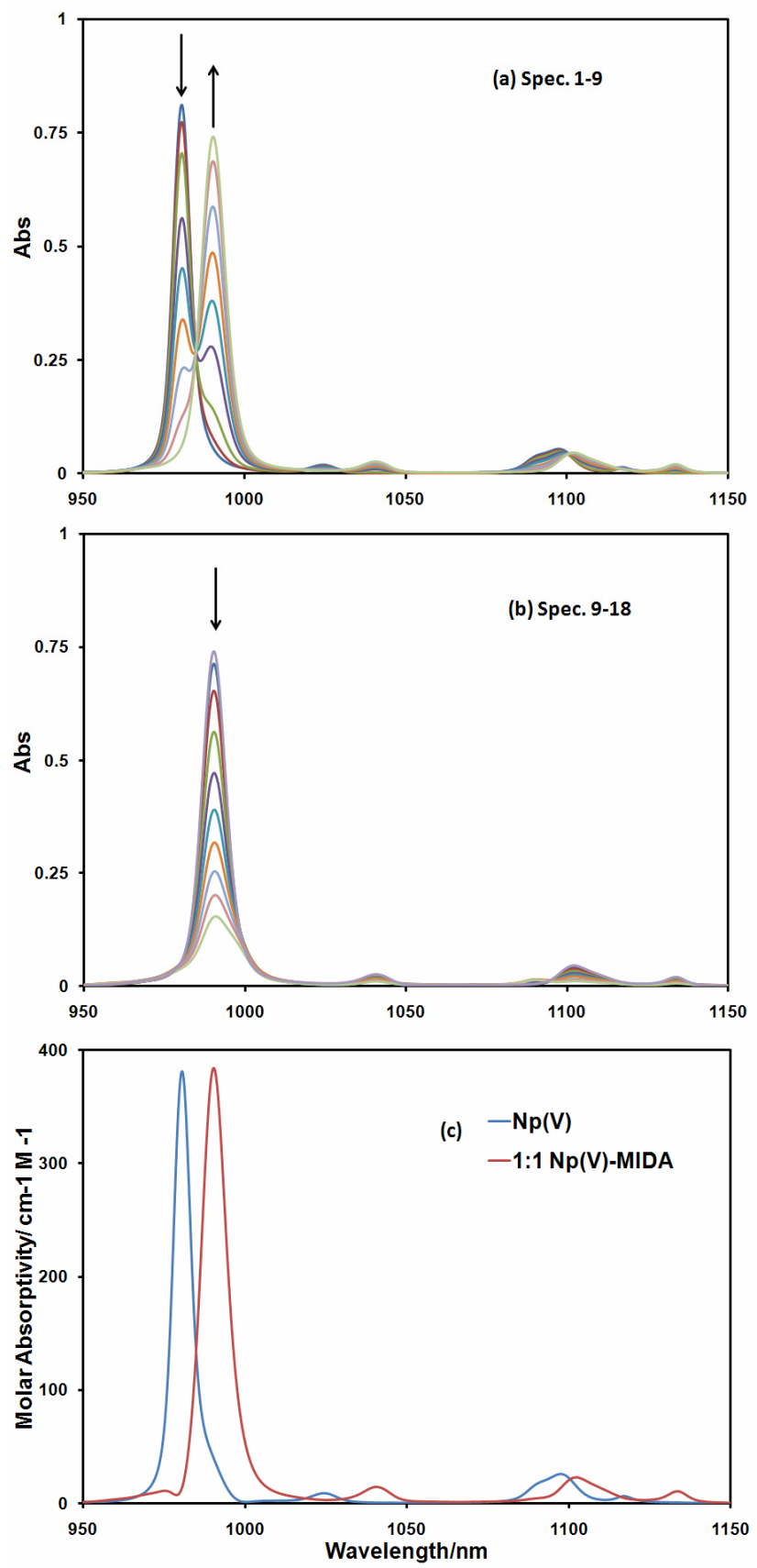

Fig. 3 Spectrophotometric titration of $\mathrm{NpO}_{2}{ }^{+}$with MIDA $\left(t=25{ }^{\circ} \mathrm{C}, I=\right.$ $1.0 \mathrm{M} \mathrm{NaClO}_{4}$ ). Cell solution: $V^{0}=2.50 \mathrm{~mL}, C_{\mathrm{Np}}{ }^{0}=2.05 \mathrm{mM}, C_{\mathrm{H}}{ }^{0}=2.37$ $35 \mathrm{mM}$. Titrant: $0.200 \mathrm{M} \mathrm{Na}_{2} \mathrm{MIDA}, 1.465 \mathrm{~mL}$ (total) added. The 18 spectra shown are not normalized in terms of $C_{\mathrm{Np}}{ }^{0}$. (a) Phase I: spectra $1-9$ $\left(C_{\mathrm{MIDA}} /\left(C_{\mathrm{Np}}+C_{\mathrm{H}}\right) \approx 0-1\right)$; (b) Phase II: spectra $9-18\left(C_{\mathrm{DPA}} /\left(C_{\mathrm{Np}}+C_{\mathrm{H}}\right)>\right.$ 1); (c) calculated absorptivities of $\mathrm{NpO}_{2}{ }^{+}$(blue) and $\mathrm{NpO}_{2}$ (MIDA) (red).

The stability constants of the $1: 1$ and $1: 2 \mathrm{~Np}(\mathrm{~V}) / \mathrm{IDA}$ 40 complexes determined by potentiometry in this work are in good agreement with the previous values ${ }^{4}$ obtained by spectrophotometry (Table 1). 
Stability constants of $\mathrm{Np}(\mathrm{V}) / \mathrm{MIDA}$ complexes by spectrophotometry and the correlation between optical absorption property and symmetry

Fig. 3 shows a representative set of absorption spectra in the ${ }_{5}$ near IR region for the titration of $\mathrm{Np}(\mathrm{V})$ with MIDA. The variation in the spectra of $\mathrm{Np}(\mathrm{V})$ during the titration can be described with two phases, I and II. In phase I (Fig. 3a), as MIDA was added, the intensities of the absorption bands at 980, $1024 \mathrm{~nm}$ that belong to the free $\mathrm{NpO}_{2}{ }^{+}$decreased, while 10 new bands appeared at longer wavelengths $(990,1039 \mathrm{~nm})$, indicating the formation of a new $\mathrm{Np}(\mathrm{V})$ species. The new bands were assigned to the $\mathrm{NpO}_{2}$ (MIDA) ${ }^{-}$complex, because the band positions agree with those of the 1:1 complex previously observed with ODA and IDA. In phase II (Fig. 3b), 15 as the concentration of MIDA was further increased, the intensities of these bands gradually decreased, but no new absorption bands appeared. The variation of spectra in the titration of $\mathrm{Np}(\mathrm{V}) / \mathrm{MIDA}$ is very similar to those observed in the complexation of $\mathrm{Np}(\mathrm{V})$ with ODA, ${ }^{9} \mathrm{DPA}^{5},{ }^{5}$ and TMOGA, ${ }^{2}$ 20 suggesting that two $\mathrm{Np}(\mathrm{V}) / \mathrm{MIDA}$ complexes formed successively during the titration, but the second complex, $\mathrm{NpO}_{2}(\mathrm{MIDA})_{2}{ }^{3-}$, did not absorb in the near IR region. Factor analysis with Hyperquad also indicates that there are only two absorbing $\mathrm{Np}(\mathrm{V})$ species (the free $\mathrm{NpO}_{2}{ }^{+}$and the $1: 1$ 25 complex). Based on this analysis, the stability constants and molar absorptivity (Fig. 3c) of the complexes were calculated.

The relationship between the optical properties and the structure of the 1:2 $\mathrm{Np}(\mathrm{V})$ complexes with ODA, DPA and TMOGA has been discussed previously. ${ }^{10}$ Because these 30 complexes are centrosymmetric with the $\mathrm{Np}$ atom at the inversion center, the f-f transitions are forbidden and they do not absorb in the near IR region. The spectrophotometric data on $\mathrm{Np}(\mathrm{V}) / \mathrm{MIDA}$ from this work indicate that $\mathrm{NpO}_{2}$ (MIDA) ${ }_{2}{ }^{3-}$ in solution is also centrosymmetric, consistent with the 35 observed structure in the crystal form. ${ }^{11}$ The correlation between the optical absorption properties and the structures of the $\mathrm{Np}(\mathrm{V}) / \mathrm{MIDA}$ complexes in the spectrophotometric titration is best illustrated in Scheme I.

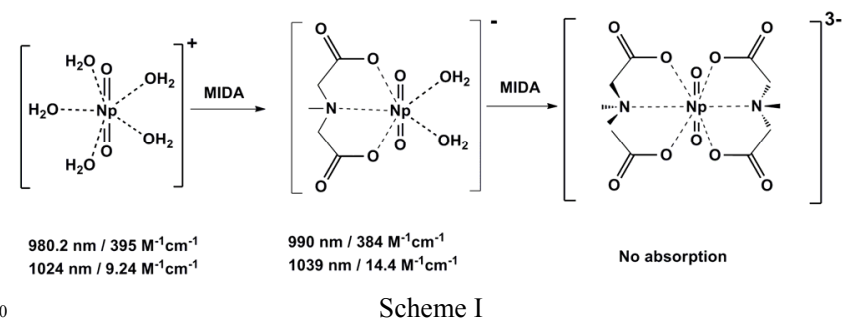

It is interesting to compare the structures and optical properties of the $1: 2 \mathrm{~Np}(\mathrm{~V})$ complexes with the three nitrilodicarboxylic acids (DPA, IDA and MIDA, Fig.1). In the DPA 45 complex, $\mathrm{NpO}_{2}(\mathrm{DPA})_{2}{ }^{3-}$, two DPA ligands coordinate to $\mathrm{Np}$ perfectly in the equatorial plane of $\mathrm{NpO}_{2}{ }^{+}$, with a $\mathrm{D}_{2 \mathrm{~h}}$ symmetry. In the IDA complex, $\mathrm{NpO}_{2}(\mathrm{IDA})_{2}{ }^{3-}$, the two iminohydrogen atoms are out of the equatorial plane and can be cis- or trans- with respect to the plane. The cis-isomer has no 50 inversion center and absorbs in the near IR region, but the tran-isomer is silent in optical absorption due to the existence of an inversion center. The energy difference between the cisand trans-isomers of $\mathrm{NpO}_{2}(\mathrm{IDA})_{2}{ }^{3-}$ is expected to be insignificant because the hydrogen atom is small, resulting in 55 the coexistence of cis- and trans- isomers of $\mathrm{NpO}_{2}(\mathrm{IDA})_{2}{ }^{3-}$ in solution. Therefore, absorption bands of $\mathrm{NpO}_{2}(\mathrm{IDA})_{2}{ }^{3-}$ with somewhat lower intensity are observed at $993 \mathrm{~nm} .{ }^{4,10}$

The $\mathrm{NpO}_{2}(\mathrm{MIDA})_{2}{ }^{3-}$ complex can also have cis- and transisomers, with the two methyl groups at the same or opposite ${ }_{60}$ sides of the equatorial plane. However, the energy difference between the two isomers is expected to be significantly larger than that in $\mathrm{NpO}_{2}(\mathrm{IDA})_{2}{ }^{3-}$. The energy of the trans- isomer should be lower due to less steric strain. As a result, only the trans- isomer forms in solution and no optical absorption is 65 observed because it is centrosymmetric with the $\mathrm{Np}$ at the inversion center.

\section{Enthalpy of complexation for $\mathrm{Np}(\mathrm{V}) / \mathrm{MIDA}$ and $\mathrm{Np}(\mathrm{V}) / \mathrm{IDA}$ complexes}

Fig. 4 shows representative sets of calorimetric titration of ${ }_{70} \mathrm{~Np}(\mathrm{~V})$ with MIDA and IDA. With the information on the speciation of $\mathrm{Np}(\mathrm{V})$ during the titration, the titration thermograms could be described as three stages. Stage I was highly exothermic and the major contribution to the heat released was from the protonation of the ligands. For the 75 titration with IDA (left), Stage I consisted of only the first addition because little free acid $(0.01 \mathrm{mM})$ was in the initial cell solution and was consumed by the IDA in the first addition. For the titration with MIDA (right), Stage I was longer ( 5 additions) because there was more free acid in the 80 initial cell solution $(1.93 \mathrm{mM})$. Integration of the peaks on the plateau of Stage I should result in the protonation enthalpy of MIDA. In both titrations, Stage II and III correspond to the formation of the $1: 1$ and $1: 2$ complexes, respectively. The titration thermograms indicate that the formation of $1: 1$ 85 complex, $\mathrm{NpO}_{2}$ (IDA) $^{-}$and $\mathrm{NpO}_{2}$ (MIDA) $^{-}$, are highly exothermic, but the formation of $1: 2$ complex, $\mathrm{NpO}_{2}(\mathrm{IDA})_{2}{ }^{3-}$ and $\mathrm{NpO}_{2}(\mathrm{MIDA})_{2}{ }^{3-}$, are only slightly exothermic,

The calculated enthalpy and entropy of complexation are listed in Table 1.

\section{Thermodynamic trends}

In general, all three nitrilo- dicarboxylic acids (MIDA, IDA DPA) form much stronger complexes with $\mathrm{Np}(\mathrm{V})$ than the oxy-dicaboxylic acids (e.g., ODA) and corresponding oxydiamides (e.g., TMOGA). In comparison, coordination by the 95 nitrilo- ligands is much more favored by enthalpy than the coordination by the oxy- ligands. For example, $\Delta H$ is -30 to $50 \mathrm{~kJ} / \mathrm{M}$ for the $1: 1 \mathrm{~Np}(\mathrm{~V})$ complexes with nitrilodicarboxylic acids (Table 1), but $+8.7 \mathrm{~kJ} / \mathrm{M}$ for the $1: 1$ $\mathrm{Np}(\mathrm{V}) / \mathrm{ODA}$ complex. ${ }^{9}$ Probably the nitrogen atom is much 100 less hydrated than the oxygen so that less de-hydration energy is required when forming the $\mathrm{Np}(\mathrm{V}) /$ nitrilo-dicarboxylate complexes. Corresponding diamide derivatives of MIDA, IDA and DPA, i.e., $N$-methyl-iminodiamide, iminodiamide and dipicolinamide, could have important applications in 105 separating neptunium due to two reasons: (1) they all are expected to coordinate with $\mathrm{Np}(\mathrm{V})$ strongly as their nitrilodicarboxylate analogs, and (2) the amide moiety allows the 
attachment of big akyl- and/or aryl- groups so that they can be used as extractants in solvent extraction.

In the series of the three nitrilo- dicarboxylic acids, the stability constants of $\mathrm{Np}(\mathrm{V})$ complexes follow the order: DPA ${ }_{5}>$ MIDA $>$ IDA (see Table 1). The high strength of $\mathrm{Np}(\mathrm{V}) / \mathrm{DPA}$ complexes could be rationalized by the "rigid" and conjugated structure of DPA in which the pyridine nitrogen and two carboxylate groups are arranged at optimal positions to coordinate with $\mathrm{NpO}_{2}^{+}$in its equatorial plane. 10 Therefore, little energy for ligand reorganization is required to form the $\mathrm{Np}(\mathrm{V}) / \mathrm{DPA}$ complexes. On the other hand, the electron donating ability of the methyl group in MIDA increases the electron density on the nitrogen, making MIDA a stronger ligand than IDA.

\section{${ }_{15}$ Conclusions}

$N$-methyl-iminodiacetic acid (MIDA) forms strong complexes with $\mathrm{NpO}_{2}{ }^{+}$, as the other nitrilo- dicarboxylic acids (IDA and DPA). The 1:2 complex, $\mathrm{NpO}_{2}$ (MIDA) ${ }_{2}{ }^{3-}$, has been identified in aqueous solution for the first time and the stability constant 20 calculated by optical absorption spectroscopy as well as potentiometry. The optical absorption properties of $\mathrm{NpO}_{2}$ (MIDA) ${ }_{2}{ }^{3-}$ are consistent with a centrosymmetric structure in which the two methyl groups are trans- with respect to the equatorial plane of $\mathrm{NpO}_{2}{ }^{+}$. In contrast to the 25 complexation of $\mathrm{Np}(\mathrm{V})$ with oxy- dicarboxylates where the complexation is not favored by enthalpy, the complexation of $\mathrm{Np}(\mathrm{V})$ with all three nitrilo- dicarboxylic aicds (MIDA, IDA and DPA) is highly favored by enthalpy, because less dehydration energy is required when forming the $\mathrm{Np}(\mathrm{V}) /$ nitrilo30 dicarboxylate complexes.

\section{Acknowledgments}

This work was supported by the Director, Office of Science, Office of Basic Energy Sciences of the U.S. Department of Energy, the Single Investigator and Small Group Research
${ }_{35}$ Program (SISGR) and the Heavy Element Chemistry Program, under Contract No. DE-AC02-05CH11231 at Lawrence Berkeley National Laboratory.

\section{Notes and references}

${ }^{a}$ Chemical Sciences Division, Lawrence Berkeley National Laboratory, 40 Berkeley, CA 94720 USA. Fax: 01510 4865596; Tel: 01 5104865427; Email:LRao@lbl.gov

1 G. Tian, L. Rao, S. J. Teat, Dalton Trans., 2010, 39, 3326-3330.

2 G. Tian, J. Xu, L. Rao, Angew. Chem., Int. Ed. 2005, 44, 6200-6203.

453 M. P. Jensen, K. L. Nash, Radiochim. Acta 2001, 89, 55-564.

4 G. Tian, L. Rao, Actinides 2005 -- Basic Science, Applications and Technology, J. L. Sarrao, A. J. Schwartz, M. R. Antonio, P. C. Burns, R. G. Haire, and H. Nitsche, Eds., (Mater. Res. Soc. Symp. Proc. 893, Warrendale, PA, 2006), Paper \# 0893-JJ05-17.

505 G. Tian, L. Rao, S. J. Teat, Inorg. Chem. 2009, 48, 10158-10164.

6 V. A. Babain, M. Yu. Alyapyshev, R. N. Kiseleva, Radiochim. Acta 2007, 95, 217.

7 J. L. Lapka, A. Paulenova, M. Yu. Alyapyshev, V. A. Babain, R. S. Herbst, J. D. Law, Radiochim. Acta 2009, 97, 291.

558 A. Paulenova, M. Yu. Alyapyshev, V. A. Babain, R. S. Herbst, J. D. Law, Sep. Sci. Technol. 2008, 43, 2606.

9 G. Tian, L.Rao, A. Oliver, Chem. Commun. 2007, 4119.

10 L. Rao, G. Tian, Symmetry 2010, 2, 1-14.

11 N. A. Budantseva, G. B. Andreev, A. M. Fedoseev, M. Yu. Antipin,

60 Doklady Chemistry 2002, 384, 159-162. Translated from Doklady Akademii Nauk. 2002, 384, 492-495.

12 E. N. Rizkalla, F. Nectoux, S. Dabos-Seignon, M. Pages, Radiochim. Acta 1990, 51, 151-155.

13 S. H. Eberle, U. Wade, U. J. Inorg. Nucl. Chem. 1970, 32, 109.

6514 L. Rao, T. G. Srinivasan, A. Yu. Garnov, P. Zanonato, P. Di Bernardo, A. Bismondo, Geochim. Cosmochim. Acta 2004, 68, 4821.

15 G. Gran, Analyst 1952, 77, 661.

16 P. Gans, A. Sabatini, A. Vacca, Talanta 1996, 43, 1739.

17 P. Zanonato, P. Di Bernardo, A. Bismondo, G. Liu, X. Chen, L. Rao, $70 \quad$ J. Am. Chem, Soc. 2004, 126, 5515.

18 R. Arnek, Ark. Kemi 1970, 32, 81.

19 NIST Standard Reference Database 46: NIST Critically Selected Stability Constants of Metal Complexes Database, Version 8.0, U.S. Department of Commerce, 2004. 

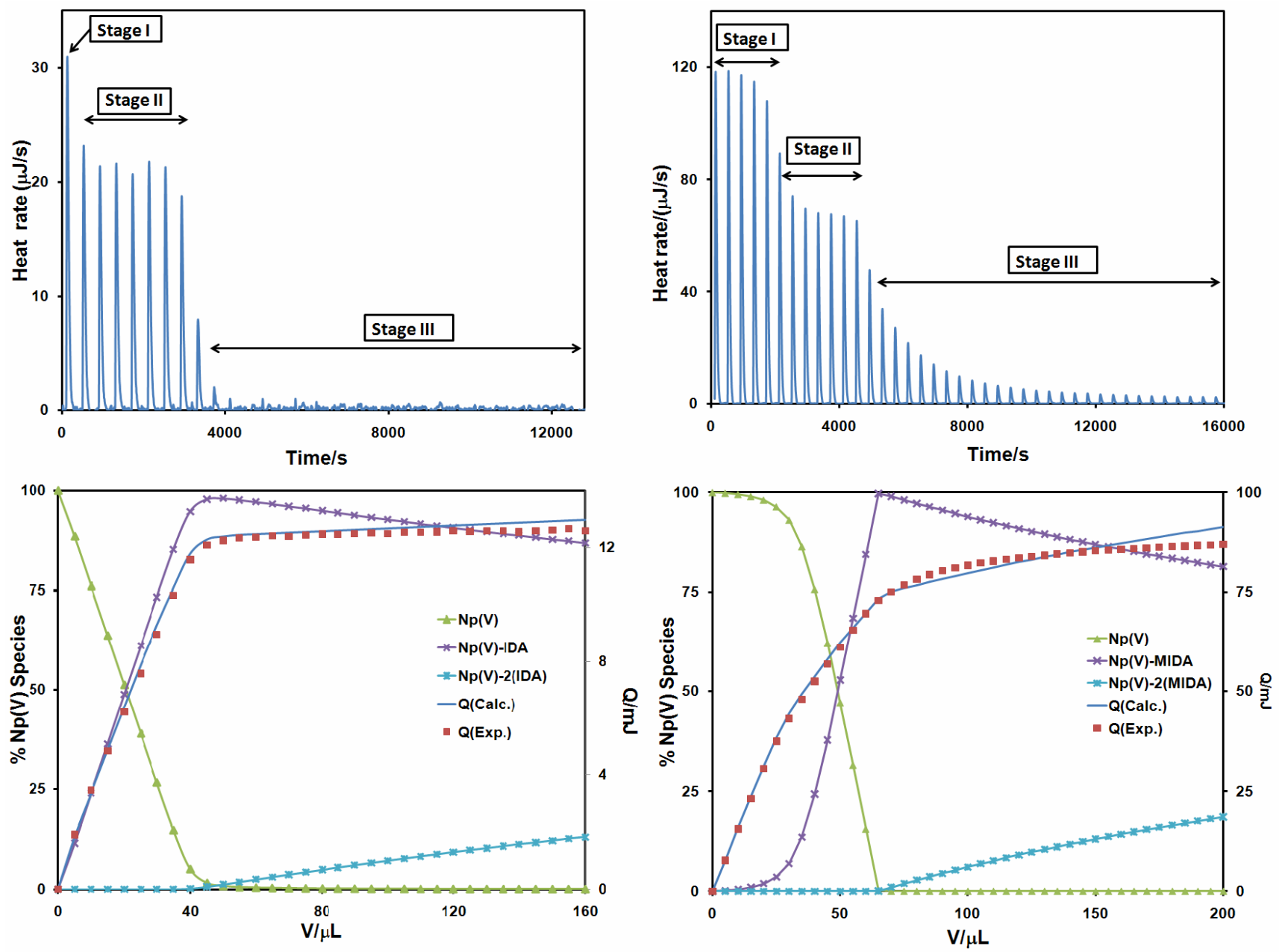

Fig. 4 Calorimetric titrations of the complexation of $\mathrm{Np}(\mathrm{V})$ with IDA and MIDA $\left(t=25^{\circ} \mathrm{C}, I=1.0 \mathrm{M} \mathrm{NaClO}_{4}\right)$. Upper figures: titration thermogram; lower figures: accumulative reaction heat (right y-axis) and speciation of $\mathrm{Np}(\mathrm{V})$ (left y-axis) $v s$. the volume of titrant. Left figures: $\mathrm{Np}(\mathrm{V}) / \mathrm{IDA} ; V^{0}=0.900$ $\mathrm{ml}, C_{\mathrm{H}}{ }^{0}=0.01 \mathrm{mM}, C_{\mathrm{Np}(\mathrm{V})}{ }^{0}=1 \mathrm{mM}$; titrant $C_{\mathrm{IDA}} / C_{\mathrm{H}}=0.025 / 0.0025 \mathrm{M}, 0.005 \mathrm{~mL} \times 34$ additions. Right figures: $\mathrm{Np}(\mathrm{V}) / \mathrm{MIDA} ; V^{0}=0.900 \mathrm{ml}, C_{\mathrm{H}}{ }^{0}=1.93$ $5 \mathrm{mM}, C_{\mathrm{Np}(\mathrm{V})}{ }^{0}=1.67 \mathrm{mM}$; titrant $C_{\mathrm{MIDA}}=0.050 \mathrm{M}, 0.005 \mathrm{~mL} \times 40$ additions. 
Table 1 Thermodynamic parameters of the complexation of $\mathrm{NpO}_{2}^{+}$with MIDA and related ligands $\left(t=25{ }^{\circ} \mathrm{C}\right)$, pot - potentiometry, sp spectrophotometry, cal - calorimetry, ix - ion exchange, p.w. - present work.

\begin{tabular}{|c|c|c|c|c|c|c|c|}
\hline Reaction & $I, \mathrm{M}$ & Method & $\log K$ & $\Delta G, \mathrm{~kJ} / \mathrm{mol}$ & $\Delta H, \mathrm{~kJ} / \mathrm{mol}$ & $\Delta S, \mathrm{~J} /(\mathrm{K} \cdot \mathrm{mol})$ & Ref. \\
\hline $\mathrm{H}^{+}+\mathrm{MIDA}^{2-}=\mathrm{H}(\mathrm{MIDA})^{-}$ & 1.0 & pot,cal & $9.45 \pm 0.03$ & $-54.95 \pm 0.2$ & $-32.7 \pm 1.4$ & $74.6 \pm 4.8$ & p.w. \\
\hline $2 \mathrm{H}^{+}+\mathrm{MIDA}^{2-}=\mathrm{H}_{2}(\mathrm{MIDA})(\mathrm{aq})$ & 1.0 & pot,cal & $11.8 \pm 0.1$ & $-67.36 \pm 0.6$ & $-31.6 \pm 2.1$ & $119.9 \pm 7.3$ & p.w. \\
\hline \multirow[t]{3}{*}{$\mathrm{NpO}_{2}^{+}+\mathrm{MIDA}^{2-}=\mathrm{NpO}_{2}(\mathrm{MIDA})^{-}$} & 1.0 & sp,cal & $7.36 \pm 0.12$ & $-42.0 \pm 0.7$ & $-16.8 \pm 2.1$ & $84.6 \pm 7.1$ & p.w. \\
\hline & & pot & $7.45 \pm 0.15$ & & & & \\
\hline & 0.5 & $\mathrm{sp}$ & $6.75 \pm 0.03$ & & & & 12 \\
\hline \multirow[t]{2}{*}{$\mathrm{NpO}_{2}{ }^{+}+2 \mathrm{MIDA}^{2-}=\mathrm{NpO}_{2}(\mathrm{MIDA})_{2}^{3-}$} & 1.0 & $\mathrm{sp}, \mathrm{cal}$ & $8.96 \pm 0.22$ & $-51.1 \pm 1.2$ & $-22.2 \pm 2.4$ & $96.9 \pm 9.0$ & p.w. \\
\hline & & pot & $9.04 \pm 0.24$ & & & & \\
\hline \multirow[t]{2}{*}{$\mathrm{NpO}_{2}^{+}+\mathrm{IDA}^{2-}=\mathrm{NpO}_{2}(\mathrm{IDA})^{-}$} & 1.0 & pot,cal & $5.85 \pm 0.22$ & $-33.4 \pm 0.7$ & $-13.5 \pm 1.8$ & $66.7 \pm 6.5$ & p.w. \\
\hline & 1.0 & sp,pot,cal & $5.88 \pm 0.01$ & $-33.57 \pm 0.06$ & $-16.0 \pm 0.2$ & $58.9 \pm 0.7$ & 3 \\
\hline $\mathrm{NpO}_{2}{ }^{+}+2 \mathrm{IDA}^{2-}=\mathrm{NpO}_{2}(\mathrm{IDA})_{2}^{3-}$ & 1.0 & $\mathrm{sp}$ & $7.62 \pm 0.04$ & & & & 4 \\
\hline $\mathrm{NpO}_{2}^{+}+\mathrm{DPA}^{2-}=\mathrm{NpO}_{2}(\mathrm{DPA})^{-}$ & 1.0 & $\mathrm{sp}, \mathrm{cal}$ & $8.68 \pm 0.11$ & $-49.6 \pm 0.6$ & $-25.2 \pm 0.7$ & $81.6 \pm 2.5$ & 12 \\
\hline $\mathrm{NpO}_{2}^{+}+2 \mathrm{DPA}^{2-}=\mathrm{NpO}_{2}(\mathrm{DPA})_{2}{ }^{3-}$ & 1.0 & sp,cal & $11.31 \pm 0.11$ & $-64.6 \pm 0.6$ & $-45.9 \pm 1.4$ & $81.8 \pm 5.5$ & 12 \\
\hline
\end{tabular}

